\title{
EVALUATION OF THE SUITABILITY OF ANTHROPOGENIC RESERVOIRS IN URBAN SPACE FOR ECOLOGICAL RESTORATION USING SUBMERGED PLANTS (UPPER SILESIA, POLAND)
}

\author{
PIERZCHAŁA, Ł. $^{1 *}$ - SIERKA, E. ${ }^{2}-$ TRZĄSKI, L. $^{1}-$ BONDARUK, J. ${ }^{1}-$ CZUBER, B. ${ }^{1}$ \\ ${ }^{1}$ Central Mining Institute, Department of water protection \\ Plac Gwarków 1, 40-166, Katowice, Poland \\ ${ }^{2}$ University of Silesia, Faculty of Biology and Environmental Protection, Department of Botany \\ and Nature Protection \\ Jagielońska 28, 40-032 Katowice, Poland \\ Corresponding authors \\ e-mail: lpierzchala@gig.eu \\ (Received 31 $1^{\text {st }}$ Mar 2015; accepted 29 ${ }^{\text {th }}$ Dec 2015)
}

\begin{abstract}
This paper presents the proposed criteria for the evaluation of mine subsidence reservoirs in areas of underground mining extraction with regard to the ability of such reservoirs to be restored and adapted to perform natural and social functions in urban space. The criteria for the evaluation of the reservoirs' potential $(\mathrm{P})$ have been analyzed, and factors crucial to the suitability (S) of the aforementioned reservoirs to be ecologically restored with the implementation of the method using submerged vegetation have been identified. The ability of the proposed criteria (qualitative - yes/no and quantitative within the range of $-2,-1,0,1,2)$ to be applied has been verified based on 4 randomly selected mine subsidence reservoirs in Upper Silesia (Poland). The obtained results show that the reservoirs are different in the evaluated potential (P: from -1 to 3) and suitability (S: from -3 to -1).

It has been concluded that the 3 proposed stages of the evaluation of reservoirs' potential and suitability to be adapted enable the categorization and determination of bodies of water for restoration activities. This is even of greater significance as, at present, mine subsidence reservoirs constitute the majority of anthropogenic reservoirs occurring in the post-mining areas.
\end{abstract}

Keywords: mine subsidence reservoirs, ecological restoration, reservoir's potential

Abbreviations: P - potential, S - suitability, ERUSV - ecological restoration using submerged vegetation, $\mathrm{SE}$ - stages of the evaluation.

\section{Introduction}

In the urban areas located on sites where the mining industry has been operating for centuries, there are numerous subsiding troughs filled with water that were formed due to the subsidence of land located above the underground excavation pits (Marschalko et al., 2009). As a result of the disturbances in the water circulation system, the reservoirs commonly constitute the only bodies of water that perform both ecological and social functions (Sierka et al., 2012), contributing to the biodiversity of the urban area by creating habitats of diverse trophy and humidity (Carpenter, 1999).

As has been shown by (Carpenter and Lathrop, 1999; Scheffer and Carpenter, 2003; Hassall, 2014; Corrigan et al., 2009), the quality of water accumulated shall be the primary factor determining both the natural and social value of reservoirs. Since mine subsidence reservoirs are frequently of shallow depth $(<6 \mathrm{~m})$, there is no thermal stratification within such reservoirs. In such bodies of water one may however observe 
the resuspension processes, i.e. the flows of biogenic substances from bottom deposits within the reservoir (Qin, 2006), as well as the process of the inflow of biogenic elements from the catchment (Scheffer et al., 2003). The aforementioned processes frequently lead to the eutrophication of reservoirs. The poor condition of anthropogenic reservoirs and the lack of complex instruments to evaluate the reservoirs' potential to perform natural and social functions are the underlying reasons why many of such bodies of water have disappeared from the landscape of areas of underground mining extraction; the reservoirs are buried with e.g. mining wastes, then the terrain is levelled out, and the site is most commonly afforested (Sierka et al., 2009). In the past some actions have been taken, however the improvement of the ecological condition of a given body of water was merely a short-term effect (Moss et al., 2003) consuming significant financial resources.

Ecological restoration using submerged vegetation (ERUSV) is one of the methods that enable obtaining the required water parameters, and is recommended for implementation in shallow reservoirs (Pan et al., 2008; Li et al., 2014). In shallow ponds, floating vegetation competes for light with submerged vegetation and requires significant amount of nutrients that it acquires from water (Portielje and Molen, 1999), often, albeit not as a rule, leading to the improvement of water quality.

However, in order to ensure the effectiveness of actions taken in the mine subsidence reservoirs in accordance with the proposed method, it appears advisable to determine reservoirs of a potential that can be used to perform, for example, the ecological function (e.g. by increasing the biodiversity) and the social function (e.g. by fulfilling the recreational and educational functions) (Naselli-Flores, 2008).

The aim of the presented paper is to provide answers for the following questions:

1. What are the decisive criteria for the evaluation of the potential of mine subsidence reservoirs to perform natural and social functions?

2. What are the features of mine subsidence reservoirs in the urban area that enable the successful implementation of the method of the reservoirs' restoration with using submerged vegetation?

3. Can the proposed criteria be used for the categorization and determination of reservoirs to restoration activities?

\section{Ecological restoration of eutrophic reservoirs}

The results of numerous research studies show that there are various reasons for the phenomenon and for the course of complex processes that occur within the reservoirs affected by eutrophication (Scheffer, 2004). At the same time, studies are taken up to analyze the possibilities of counteracting and limiting the phenomenon of eutrophication of surface water reservoirs (inter alia, Cooke, 1993; Schindler, 2006; Mitsch and Gosselink, 2007; Ciecierska, 2008 and others). In order to effectively restore reservoirs' functions that have been lost due to excessive fertilization, ecological condition of such reservoirs should be assessed, as well as other specific local conditions (e.g. salinity) should be analyzed, so that the potential of such reservoirs and the methods of their restoration could be defined (Gächter and Imboden, 1985; Rooney and Bayley, 2010). Forming buffer vegetation within a reservoir's shore zone may serve as a good example of an effective biological method of reducing the inflow of biogenic compounds (Millar, 2010). With regard to shallow reservoirs with slightly sloping shores (Sierka et al., 2012), effective methods of reducing the mass development of phytoplankton are, inter alia, the biological restoration methods aimed 
to the development of submerged vegetation (Jeppesen, 2007; Pan et al., 2008; Li et al., 2014), which is indicated by the results of research conducted in the Karvina area in the Czech Republic (Pierzchała, 2011), and in other areas (Boesch et al., 2001; Kosten et al., 2009, e.g. in Florida (Moreno, 2011).

Among researchers, Bradshaw (1997); Søndergaard (2007); Rooney and Bayley (2010) have developed and tested the methods of assessing the effectiveness of the already implemented restoration activities of urban areas within which there are numerous water reservoirs (Jankowski et al., 2001). The restoration balance can also be run by means of comparison between the monetary value of the area before and after the planned restoration activities (Trząski and Mana, 2008). Due to significant diversification of anthropogenic mine subsidence reservoirs, with regard to hydromorphological, hydrochemical, and ecological features (Sierka et al., 2012), as well as to their locational characteristics, it is necessary to evaluate the reservoirs on the basis of the functions that are crucial for the reservoirs' target functions.

There are more than 300 mine subsidence reservoirs in the area of Upper Silesia, and new ones are formed all the time (Jankowski and Rzętała, 2004). Unfortunately, not all the reservoirs have the opportunity to function in the urban area without any support; therefore it is necessary to identify their potential with regard to the target functions that they are to perform.

\section{Water reservoir potential evaluation in urban space}

The "best attainable condition" of reservoirs, sensu Stoddard et al., (2006), located in urban areas, is the aim of institutions that are responsible for such reservoirs. The above follows from numerous functions fulfilled by ecosystems of water reservoirs located in urban areas (Bolund and Hunhammar, 1999; de Groot, 2010; Peres and de Silvia, 2013).

Up till now, especially in the area of the Silesian metropolitan area, there have been several successful cases of river restoration (Słowik, 2015; Bender et al., 2012). The activities consisted mainly in restoring their recreational and ecological functions by e.g. restoring the plant community similar to the natural one within the anthropogenic river valleys. However, all the objects which have been restored were chosen on the basis of accepted criteria for evaluation of their potential, so that they would be able to perform the expected functions in the urban area (Trząski et al., 2008).

The principles of an effective adaptation of postindustrial areas, including the mine subsidence water reservoirs, the descriptions of best practice and the most common obstacles found during the implementation of the investment in this type of objects have been presented in works (Mušič and Cotič, 2006; Petríková and Vojvodíková, 2012).

The criteria for the evaluation of such areas, enabling the researchers to define the most advantageous form of adaptation of such areas (their form of use) have been worked out within a method developed by Trząski et al. (2008). The algorithm takes into consideration factors such as the origins of the area and legal and environmental regulations, and on this basis, it calculates the point values. Another example of ranking areas for the purpose of restoration, with regard to the function that the areas are to perform as a target, is the residential areas for various target groups of residents, including the residents coming from various parts of the world (Aravot, 2010). The ranking list has also been prepared for the selection of projects implemented in the field of rail transportation in Serbia, and it was based on the developed algorithm (Mandic et al., 2014). 
The review of methods of evaluating the usefulness of a reservoir for ecological restoration that are mainly based on one of the criteria, e.g. the diversification of vegetation (Pierzchała and Sierka, 2009) shows that current literature lacks methods combining various criteria for evaluating the potential of this type of reservoirs for restoration. They are indispensable due to the need to particularize the tools to support decision-making in the area of adapting and administering objects in the urban area so that the method could be applied: (1) as a quick and reliable tool for reaching, establishing, and examining decisions; and (2) as a means to evaluate an area of subsidence water reservoirs for defining the functions prior to the planning process.

\section{Materials and methods}

\section{The criteria and stages of the evaluation of suitability of reservoirs for ERUSV}

The criteria for the evaluation of suitability of a reservoir for ecological restoration with the use of the method supporting the growth of submerged vegetation have been proposed based on: i) the data included in published papers that refer to the issues of the ecology, functioning, and restoration of shallow reservoirs; ii) the results of research concerning the functions performed by mine subsidence reservoirs in the ecological and social environments, and; iii) the rules and good practices for the management of water bodies in the urban areas.

The evaluation $(S E)$ has been conducted in 3 stages: I - the evaluation qualifying a reservoir for ecological restoration (admission); II - the evaluation of the reservoir's potential to perform the ecological and social functions in the urban area; III - the evaluation of the reservoir's suitability to be ecologically restored.

The scope and meaning of the particular stages has been presented in Figure 1.

\begin{tabular}{|c|c|c|}
\hline & & SCOPE \\
\hline \multirow{3}{*}{ 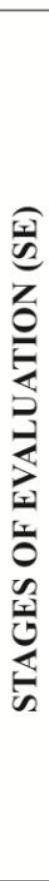 } & $\begin{array}{c}\text { SE 1 } \\
\text { Admission }\end{array}$ & $\begin{array}{l}\text { Analysis of the: } \\
\text { 1.1. legal and formal conditions } \\
\text { 1.2. pollutant sources } \\
\text { 1.3. reservoir's ecological condition } \\
\text { STAGE } 1 \text { OF THE EVALUATION DETERMINES THE FORMAL } \\
\text { FEASIBILITY OF CONDUCTING RESTORATION } \\
\text { ACTIVITIES WITH THE USE OF THE METHOD } \\
\text { SUPPORTING THE GROWTH VEGETATION ON } \\
\text { A GIVEN SITE }\end{array}$ \\
\hline & $\begin{array}{c}\text { SE } 2 \\
\begin{array}{c}\text { The reservoir's } \\
\text { potential }\end{array}\end{array}$ & $\begin{array}{l}\text { Analysis of the: } \\
\text { 2.1. reservoir's location conditions } \\
\text { 2.2. shore zone character } \\
\text { 2.3. impact of mining extraction } \\
\text { STAGE } 2 \text { OF THE EVALUATION DETERMINES THE POTENTIAL } \\
\text { OF THE RESERVOIR TO PERFORM THE NATURAL } \\
\text { AND SOCIAL FUNCTIONS IN THE URBAN AREA }\end{array}$ \\
\hline & $\begin{array}{c}\text { SE } 3 \\
\text { The reservoir's } \\
\text { suitability }\end{array}$ & $\begin{array}{l}\text { Analysis of the: } \\
\text { 3.1. reservoir's depth and bottom relief } \\
\text { 3.2. projected alterations connected with impact of mining } \\
\text { 3.3. hydrological regime } \\
\text { 3.4. structure of the ichthyofauna } \\
\text { STAGE 3OF THE EVALUATION DETERMINES THE USEFULNESS } \\
\text { OF THE RES R R O IR FOR THE E F FECTIVE } \\
\text { IMPLEMENATION OF ECOLOGICAL RESTORATION } \\
\text { USING SUBMERGED VEGETATION }\end{array}$ \\
\hline
\end{tabular}

Figure 1. Stages of evaluation (SE) of the suitability of a reservoir to be ecologically restored under the assumed criteria 
In the stage 1, which is the evaluation that qualifies a reservoir for ecological restoration, a dichotomous scale (yes/no) has been applied, whereas in the two remaining stages a five-point ordinal scale has been applied:

2 - a positive factor of high importance;

1 - a positive factor of moderate importance;

0 -a neutral factor or a factor whose negative and positive impacts mutually counterbalance each other;

-1 - a negative factor of moderate importance;

-2 - a negative factor of high importance.

The analyzed factors have both positive and negative effects on the final value of the evaluation of the ecological and social potential of a reservoir (Tab. 1). A negative value demonstrates a low potential (the min. value -5 ), whereas positive value indicates the presence of positive factors that are favourable for the adaptation of a reservoir for performing ecological and social functions (max. value 4).

Table 1. Criteria for the evaluation of the potential of a mine subsidence reservoir to perform the natural and social functions in the urban area (Stage 2).

\begin{tabular}{|c|c|}
\hline Shore zone character & Points \\
\hline $\begin{array}{c}\text { More than } 50 \% \text { of the reservoir's shoreline constitutes a favourable habitat for the development } \\
\text { of reed vegetation }\end{array}$ & 2 \\
\hline $\begin{array}{l}\text { Less than } 50 \% \text { of the reservoir's shoreline constitutes a favourable habitat for the development } \\
\text { of reed vegetation }\end{array}$ & 1 \\
\hline The shore zone character renders the development of reed vegetation impossible & -1 \\
\hline \multicolumn{2}{|l|}{ The current type of use of the reservoir } \\
\hline The reservoir located in a developed area of recreational character (parks, gardens) & 2 \\
\hline $\begin{array}{c}\text { The reservoir of a good accessibility, communicated with objects of public utility and/or } \\
\text { residential development (with a direct access to a public road or a hard surfaced pedestrian/cycle } \\
\text { path) }\end{array}$ & 1 \\
\hline $\begin{array}{l}\text { Physically limited access to the reservoir, e.g. a convenient access to the reservoir only on foot, } \\
\text { while there are no significant obstacles to improve the reservoir's accessibility }\end{array}$ & 0 \\
\hline $\begin{array}{l}\text { Poor access to the reservoir, however, there are no significant zoning or legal obstacles to } \\
\text { improve the reservoir's accessibility }\end{array}$ & -1 \\
\hline The improvement of the reservoir's accessibility impossible or highly hindered & -2 \\
\hline \multicolumn{2}{|l|}{ Impacts of mining } \\
\hline $\begin{array}{l}\text { The process of deformation has been finished or does not threaten the planned technical } \\
\text { infrastructure }\end{array}$ & 0 \\
\hline $\begin{array}{l}\text { Significant changes to the size of the subsiding trough projected (for the time being, it is not } \\
\text { possible to adapt the reservoir) }\end{array}$ & -2 \\
\hline
\end{tabular}

A negative evaluation of the suitability of a reservoir for ERUSV indicates the predominance of factors that adversely affect the effectiveness of the restoration method supporting the growth of submerged vegetation to improve the condition of the reservoir's waters (min. value -8$)(T a b .2)$. Reservoirs of the evaluation value equal to 0 
do not indicate the occurrence of any adverse factors for the successful implementation of ERUSV.

Table 2. Criteria determining the suitability of a reservoir for ecological restoration

\begin{tabular}{|c|c|}
\hline \multicolumn{2}{|l|}{ Basin shape } \\
\hline More than $50 \%$ of the bottom constitutes a favourable habitat for submerged vegetation & 0 \\
\hline $25-50 \%$ of the bottom constitutes a favourable habitat for submerged vegetation & -1 \\
\hline Less than $25 \%$ of the bottom constitutes a favourable habitat for submerged vegetation & -2 \\
\hline \multicolumn{2}{|l|}{ Impacts of mining } \\
\hline $\begin{array}{l}\text { The subsidence has no impact on the share of bottom constituting a favourable habitat for } \\
\text { submerged vegetation (the phytolithoral zone ) }\end{array}$ & 0 \\
\hline The projected subsidence may reduce the share of the phytolithoral zone to the level of $25-50 \%$ & -1 \\
\hline The projected subsidence may reduce the share of the phytolithoral zone to the level below $25 \%$ & -2 \\
\hline \multicolumn{2}{|l|}{ Fluctuations of the level of water } \\
\hline The level of water is stable (amplitude of the water level fluctuations up to $1 \mathrm{~m}$ ) & 0 \\
\hline The level of water is subject to fluctuations (from $1 \mathrm{~m}$ to $2 \mathrm{~m}$ ) & -1 \\
\hline The level of water is subject to significant fluctuations $(>2 \mathrm{~m})$ & -2 \\
\hline \multicolumn{2}{|l|}{ Structure of the ichthyofauna } \\
\hline A reservoir of a balanced structure of ichthyofauna & 0 \\
\hline $\begin{array}{l}\text { A reservoir of a disturbed structure of ichthyofauna, yet it is possible to conduct the } \\
\text { biomanipulation process (stocking under } 20 \mathrm{~g} \text { per } \mathrm{m}^{2} \text { and/or no predatory species and/or } \\
\text { presence of introduced plantivorous species) }\end{array}$ & -1 \\
\hline $\begin{array}{c}\text { Biomanipulation process impossible } \\
\text { (e.g. in the event where the reservoir is intensely used for angling purposes) }\end{array}$ & -2 \\
\hline
\end{tabular}

The sequence of reservoirs to be covered by restoration activities is determined based on the evaluation value from the third stage - the higher the value, the sooner the ecological restoration of a particular reservoir (ERUSV) should be conducted.

\section{Description of evaluation stages}

In the stage 1, which is the evaluation qualifying a reservoir for restoration (Fig. 2.) following issues were included:

1.1 Legal and formal conditions - shall include the analysis of the ownership structure, the form of land possession, and the legal status of the reservoir and the surrounding area.

Mine subsidence reservoirs occur both in uncultivated lands and developed lands. Thus, the ownership structure is frequently complex.

The more owners (who usually represent conflicting interests) there are, the more difficult, if not impossible at all, it is to conduct restoration and adaptation of a given object. The restoration activities may include the improvement of the quality of water in the reservoir and its immediate neighbourhood, as well as the development of infrastructure that will enable the object to be used for the purpose of recreation. The most favourable situation is where the owner of the reservoir is a local government 
public entity or a legal person, in whose interest it is to use the reservoir's potential to perform ecological and social functions. Thus, prior to taking any actions, it is necessary to conduct an analysis of the planning documents that refer to the particular area, i.e. the local zoning plan. It is possible to realize the tasks only in a situation, where the type of the land use purpose is designated for surface water, or its most favourable designation is recreational space and space of ecological functions.

In the event where no explicit reservoir's use purpose is indicated in the planning documents, it is required to verify the planned method of restoration within the framework of repairing mining-related damages (contents of the mining plant operation plan) and the decision concerning the forest and farmland conversion for the purpose of mining projects (e.g. The Act of 9 June 2011 on the Geological and Mining Law, Art. 108. Dz.U. 2011 No. 163 item 981. and The Act of 3 February 1995 on the Protection of Agricultural and Forests Land, Art. 10. Dz.U. 2004 No. 121 item 1266).

1.2 Pollutant sources - shall include the analysis of the reservoir's catchment with regard to the identification of the potential and actual pollutant sources, including in particular biogenic compounds, pesticides, and heavy metals.

With regard to drainage reservoirs, the analysis should cover the immediate catchment of the reservoir (the area from which waters feed the reservoir by overland flows and infiltration), as well as all watercourses that communicate with the reservoir. The analysis should be conducted with regard to the occurrence of dumping of domestic and industrial wastewater, areas of intense agricultural production, and landfills, from where contaminants feed or may feed the analyzed reservoir directly, or through its catchment. In the event where the reservoir is supplied with biogenic substances or other pollutants, in the first place, comprehensive activities should be conducted in order to:

-settle the waste management within the reservoir's catchment;

-reduce the migration of pollution (by changing the form of use purpose, creating geochemical barriers, buffer zones or shallow pools in the form of wetlands on the reservoir's tributaries);

-remove pollution that may constitute a sanitary threat or a secondary source of supplying the reservoir with biogenic substances.

If there is no possibility of reducing the reservoir's excessive pollution load from external sources, the ecological restoration of the reservoir should be considered pointless, as there is virtually no chance to improve the quality of water of the analyzed object.

1.3 The reservoir's ecological condition - shall include the evaluation performed in accordance with the regulations of the Water Framework Directive (the 2000/60/EC DIRECTIVE), and the analysis of the indicators of the reservoir's quality of structure and functioning.

The main indicator of the good condition of reservoir's water is the occurrence of specified groups of living organisms, e.g. the aquatic vegetation. The physico-chemical parameter that is decisive for the development of this kind of vegetation is the water transparency that conditions the ability of sunlight to penetrate the water (Scheffer, 1998). The availability of sunlight is a factor vital to the development of structures with predominance of submerged vegetation, which constitutes the primary indicator of a good ecological condition and stability of an aquatic ecosystem. The degradation processes in shallow reservoirs reduce the water transparency, which is commonly the 
result of an increase in the phytoplankton biomass that may lead to the recession of submerged vegetation.). A quick and easy to interpret indicator of water quality is water transparency measured with the use of Secchi disc and given in [m] (Padial et al., 2008). A persistent regime with transparent water is perceived as the more desired one due to a greater utility value and a greater biologic diversity of a water reservoir with such a regime (Moss, 1998; Scheffer, 2004). For the purpose of a paper it has been assumed (Moss et al., 2003) that reservoirs of water transparency above $1 \mathrm{~m}$ and with submerged vegetation are characterized by a good ecological condition and do not require the application of the described method (ERUSV). Water reservoirs which require ecological restoration (poor ecological condition) are characterized by water transparency at the level $<1 \mathrm{~m}$, and the lack of submerged vegetation.

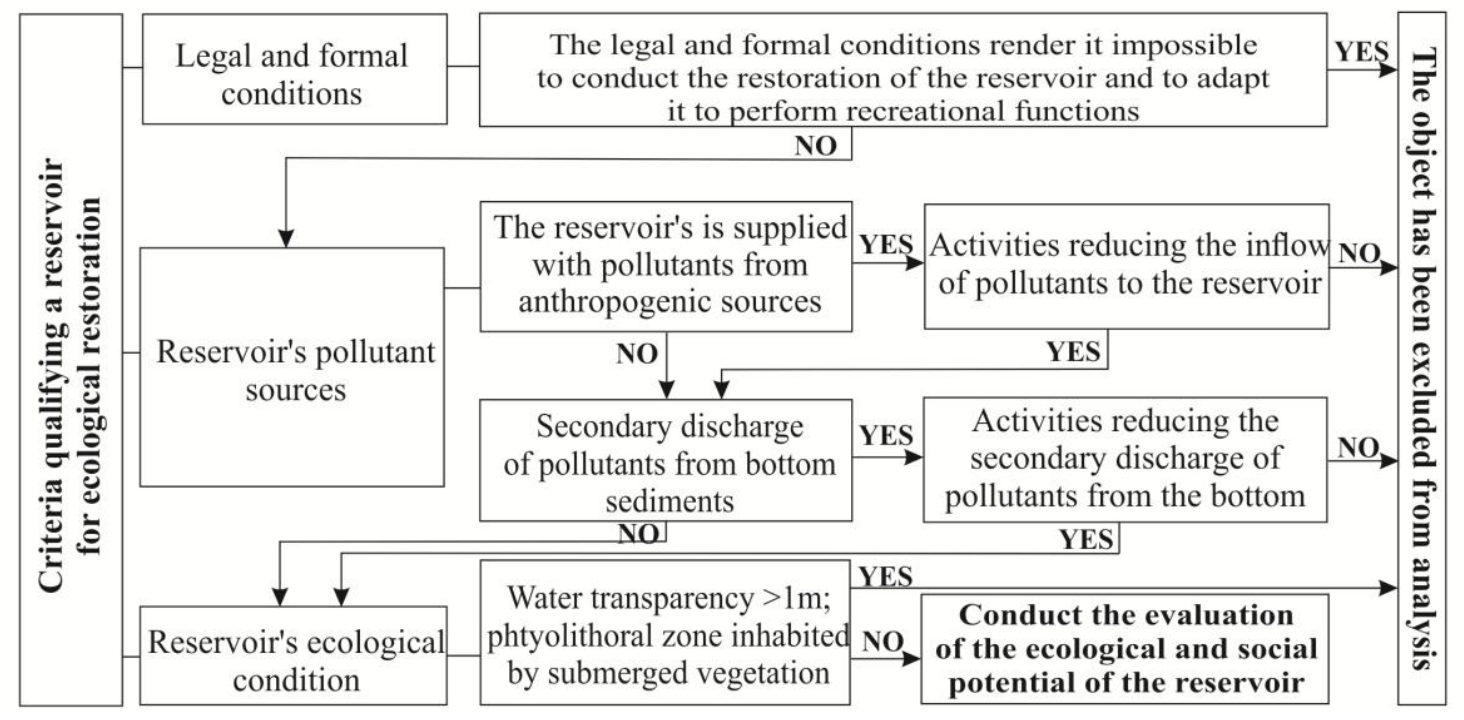

Figure 2.The logic diagram for conducting the process of evaluation qualifying a reservoir for restoration (stage 1) with the use of the submerged vegetation (authors' own study).

In the stage 2, which is evaluation of the ecological and social potential of the reservoir (Table 1) following issues were taken into consideration:

2.1 Location and the current type of use of the reservoir - shall include the analysis of the reservoir's location with regard to the proximity to important objects of public utility and residential development.

The recreational potential of a reservoir is determined by its accessibility, which is the location of a reservoir in close proximity to objects of public utility (i.e. parks, gardens) and residential development.

In the event where there is poor access to a reservoir, it should be analyzed whether there are any legal or zoning obstacles that could prevent the reservoir from performing ecological and social functions (building of access roads, pedestrian and cycle paths).

2.2 Shore zone character - shall include the analysis of the structure of the bottom and the slope of shores of the reservoir, which constitute the parameters determining the reservoir's potential. 
The shores of mine subsidence reservoirs are frequently characterized by technical lining with mining wastes such as waste rock or concrete slabs, and by slope that renders the development of shoreline reed vegetation difficult or even impossible. In addition to their aesthetic value, such communities perform a series of significant ecological functions (they, inter alia, prevent erosion, reduce the inflow of biogenic substances from the catchment, and constitute habitats for waterfowl). The shore slope optimal for the development of reed vegetation is approximately 1:15 (Sierka et al., 2012) Shores of such a slope are safe for the users of the reservoir and ensure the use of the reservoir for various recreational purposes (Avakyan, 1986; Pierzchała and Sierka, 2009; Świerk and Szpakowska, 2009).

2.3 Impacts of mining - shall include the analysis of the dynamics of the subsidence through in which the reservoir has been formed due to the land subsidence, and of the depositions of impermeable layers close to the surface.

The processes of the mine subsidence reservoir's size changes, caused by the collapse of underground mine voids, continue for many years (Marschalko et al., 2009) after the mining operations have been abandoned. Lands within an active subsidence area are characterized by a reduced capability of being developed due to the risk of destroying the technical infrastructure prepared for the recreational use. In order to reduce the potential losses, reservoirs located in subsiding troughs of high level of projected subsidence should not be adapted for recreational purposes.

Evaluation of the suitability of a reservoir for ecological restoration using the submerged vegetation (stage 3 ) includes the following issues:

3.1 Basin shape - shall include the analysis of the depth and the shape of the reservoir's bottom with regard to the possibility of enrooting and growth of submerged vegetation species such as for example Myriophyllum spp.

The vegetation in undisturbed lake occurs, in average, to the depth of 2-2.5 m (Ciecierska and Kolada, 2014); the surface of the reservoir's bottom up to such depth determines the potential area to be inhabited by submerged vegetation. The study (Hilt et al., 2006) has shown that the required water parameters can be maintained by submerged vegetation only in a situation, where the reservoir's inhabitation is at least at the level of $50 \%$. Significant slope of the bottom is unfavourable for the development of vegetation due to the amplified impact of waves and leads to the increase of fluctuation in the level of water in the reservoir (Weisner, 1997; Krolová, 2010). Duarte and Kalff (1986) have proven that in the littoral zone the bottom slope of even 5.33\% (1:19) may significantly reduce the occurrence of submerged vegetation. With regard to reservoirs that do not meet the aforementioned criteria, the effectiveness of restoration activities, using the method supporting the development of submerged vegetation, may be limited. Nevertheless, one cannot exclude the possibility that the inhabitation of a smaller area of the reservoir by aquatic vegetation will be sufficient to maintain the required water parameters. The research (Meijer et al., 1999) has shown that the reservoirs inhabited by submerged vegetation at the level of 25\%, and according to Portielje and Molen (1999) at the level of merely $5 \%$, are characterized by a higher transparency of water than reservoirs that are not inhabited by such kind of vegetation.

3.2 Impacts of mining - shall include the analysis of the changes of the basin shape in terms of the change of the bottom's depth and relief (point 2.3.) that may reduce or 
even prevent the development of the submerged vegetation. The deepening of the reservoir, as a result of the process of the bottom subsidence, will reduce the ability of sunlight to penetrate water and will lead to the decrease of the percentage of the area favourable for the development of the submerged vegetation (Weisner et al., 1997). Significant deformation of the area may therefore considerably affect the effectiveness of the analyzed method of restoration (ERUSV) of shallow water reservoirs, including, in particular, the reservoirs of large slope of shores.

3.3 The hydrological regime - shall include the analysis of the level of water in the reservoir that may affect the development of submerged vegetation.

The horizontal water movements directly and indirectly affect the aquatic vegetation. A significant increase in the water level, in particular at the beginning of the vegetation season, reduces the growth of submerged vegetation by reducing the sunlight ability to penetrate water. Low level of water may, on the other hand, be directly harmful to the submerged vegetation, causing drying up of the plants or leading to damage resulting from the impact of waves (Coops et al., 2003; Bornette and Puijalon, 2011; Cao et al., 2012). The observations of storage reservoirs, in which the fluctuations of the water level exceeded $2 \mathrm{~m}$, have shown that such reservoirs are characterized by poor development of vegetation or even by the lack of vegetation in the littoral zone (Prus et al., 2006). Cao et al. (2012) has, on the other hand, proven that the amplitude of water level fluctuations exceeding $1 \mathrm{~m}$ may significantly reduce the dynamics of the growth of submerged vegetation.

3.4 Structure of the ichthyofauna - shall include the analysis of the structure and composition of species of the ichthyofauna that may affect the development of the submerged vegetation.

Reservoirs that are mainly stocked with zooplanktivorous fish are characterized by an excessive growth of phytoplankton, and as a consequence, the water transparency in such reservoirs is reduced (Scheffer, 1989; Mazurder et al., 1990; Eppesen et al., 1997; Gorman et al., 2014). In addition to the above, introducing the plantivorous species (Ctenopharyngodon idella) and species that feed in the bottom sediments (Cyprinus carpio) by the anglers significantly reduces the reservoir's possibility to create the predominance of submerged vegetation in the given reservoir. In most cases, the predominance of macrovegetation is possible only in the event where the fish stocking of the reservoir does not exceed $20\left[\mathrm{~g} \cdot \mathrm{m}^{-2}\right]$ (Moss et al., 2003). If the fish stocking exceeds this value, the first step to be taken within the restoration should be the biomanipulation process (the reduction of the plantivorous and zooplanktivorous fish species and stocking the reservoir with predatory species). The lack of consent of an angling club or association for activities of this type makes the process of supporting the development of submerged vegetation in the restored reservoir less likely to be successful.

Since vegetation makes it difficult to angle and disturbs the access to water, vegetation is commonly removed from the shoreline zone, which very often also refers to the submerged vegetation.

\section{Area of study}

In order to verify the proposed criteria for evaluation, a study has been conducted on 4 randomly selected mine subsidence reservoirs (Table 3), located in the area of Bytom (Fig. 3). 
Table 3. Characteristics of objects of the study.

\begin{tabular}{|c|c|c|c|c|c|}
\hline Item & Name & Area [ha] & $\begin{array}{c}\text { Average } \\
\text { depth [m] }\end{array}$ & Location & Characteristics \\
\hline I & Pond 36 & 1.1 & 2 & $\begin{array}{c}\text { N: } 50^{\circ} 21^{\prime} 15.74^{\prime \prime} \\
\text { E: } 18^{\circ} 54^{\prime} 10.17^{\prime \prime}\end{array}$ & $\begin{array}{c}\text { Reservoir with no outflow within } \\
\text { park area }\end{array}$ \\
\hline II & Pond 1 & 1.2 & 1,5 & $\begin{array}{c}\text { N: } 50^{\circ} 19^{\prime} 35.25^{\prime \prime} \\
\text { E: } 18^{\circ} 53^{\prime} 46.51^{\prime \prime}\end{array}$ & $\begin{array}{c}\text { A flow-through reservoir in the } \\
\text { valley of Bytomka River }\end{array}$ \\
\hline III & Pond 24 & 22 & 2,5 & $\begin{array}{c}\text { N: } 50^{\circ} 22^{\prime} 0.09^{\prime \prime} \\
\text { E: } 18^{\circ} 52^{\prime} 9.84^{\prime \prime}\end{array}$ & $\begin{array}{c}\text { Reservoir with no outflow } \\
\text { formed within uncultivated, } \\
\text { agricultural and forest area }\end{array}$ \\
\hline IV & Pond 32 & 0.95 & 2 & $\begin{array}{c}\text { N: } 50^{\circ} 21^{\prime} 40.24^{\prime \prime} \\
\text { E: } 18^{\circ} 54^{\prime} 56.27^{\prime \prime}\end{array}$ & $\begin{array}{c}\text { Reservoir with no outflow } \\
\text { formed within uncultivated area }\end{array}$ \\
\hline
\end{tabular}

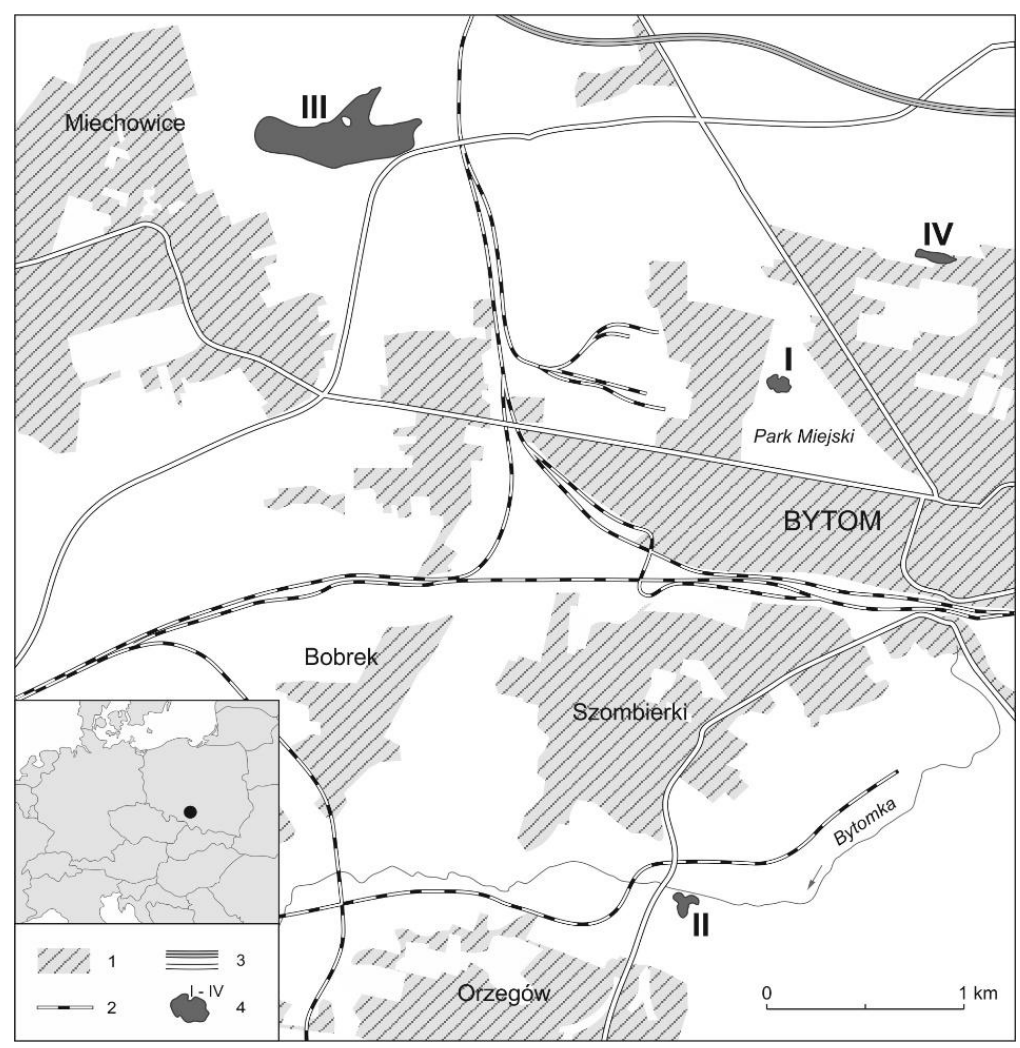

Figure 3. Location of the object of study. Explanation: I - Reservoir no. 36; II-Reservoir no. 1; III-Reservoir no. 24; IV-Reservoir no. 32.

The information used to the analysis was derived from the following sources:

1. A complex project concerning the identification and liquidation of undrained subsidence occurring within the area of operation of Bytom Mine Restructuring Company Sp. z o.o., Publication of Agos-Gemes Sp. z o.o. and Bytomskie Przedsiębiorstwo Komunalne Sp. z o.o., Katowice, Bytom 2006. 
2. The detailed design for the cleaning of the bottom of the Northern Pond (pond no. 36, the reconstructionof a section of storm water system, and the pond's inlet and outlet along witha lift station - within the framework of the project: Land Redevelopment of the historic Kachel's City Park in Bytom Documentation of the plus8.pl s.c. Zabrze, Bytom 2010.

3. A specialist hydrogeological-mining-construction opinion verifying the participation of Bytom Municipality, Kompania Węglowa S.A. - the KWK "Bobrek-Centrum" affiliate, Mine Restructuring Company S.A., and other entities in the operating costs of draining undrained overflow lands in the area of Bytom Municipality. Documentation of the Central Mining Institute in Katowice, Bytom 2011.

4. Disposal of illegal landfill and restoration of overflow land in the area of Kolonia Zgorzelec in Bytom. Tender documentation for a project realized by Bytom Municipality within the framework of the Programme for the Development of the Central Subregion - the Regional Operational Programme of the Silesia Voivodship 2007-2013.

\section{Results}

With regard to the legal and formal conditions, the characteristics of the reservoir III appear to be the least favourable. The complex ownership structure of the reservoir renders it difficult to restore and adapt the analyzed object, yet it does not render it impossible. All the reservoirs demonstrate no pollutant sources or accumulation of pollutants in bottom sediments. Three of the four analyzed reservoirs have been qualified for ecological restoration (ERUSV), i.e. the reservoirs I, III, and IV. The evaluation of the reservoir II has shown that due to its good ecological condition, the reservoir does not require to be restored with the use of the indicated method (ERUSV) (Tab. 4).

\section{The evaluation of the potential of the reservoir to perform the natural and social functions in the urban area}

The reservoir I is characterized by the highest potential to perform the natural and social functions (Fig. 4).

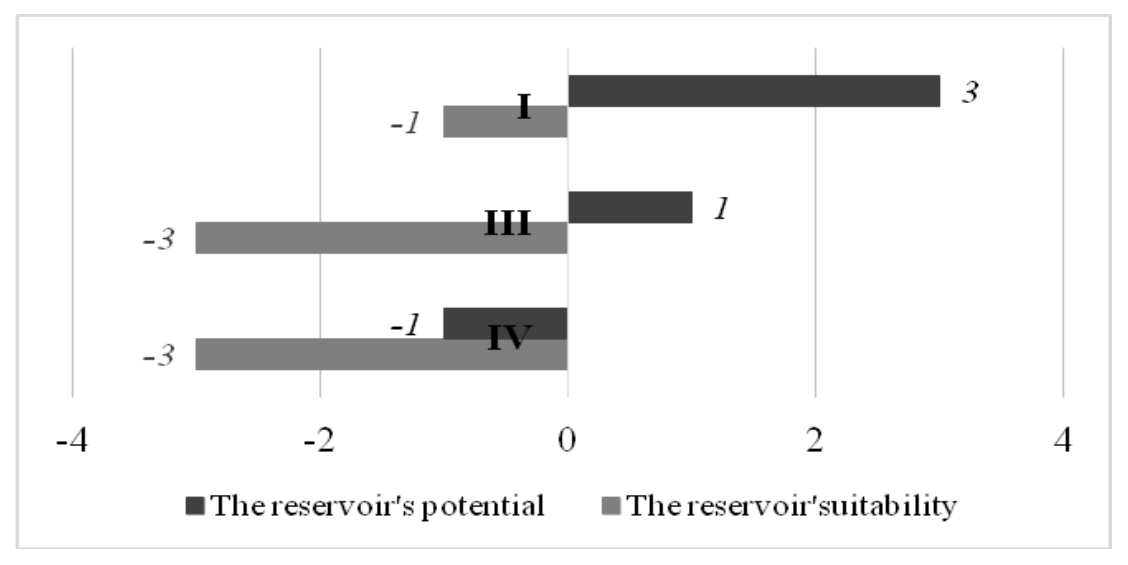

Figure 4. The evaluation of the potential and suitability of mine subsidence reservoirs (the authors' own study) 
Table 4. The results of the evaluation of particular reservoirs - case study.

\begin{tabular}{|c|c|c|c|c|c|c|c|c|c|}
\hline \multirow{2}{*}{ 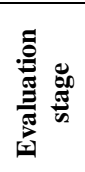 } & \multirow[b]{2}{*}{ } & \multicolumn{2}{|r|}{ Reservoir I } & \multicolumn{2}{|r|}{ Reservoir II } & \multicolumn{2}{|r|}{ Reservoir III } & \multicolumn{2}{|r|}{ Reservoir IV } \\
\hline & & 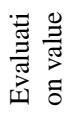 & Justification & 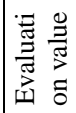 & Justification & 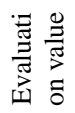 & Justification & 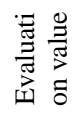 & Justification \\
\hline \multirow{4}{*}{ 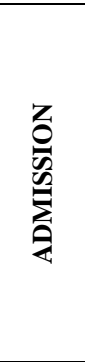 } & 1.1 & Yes & $\begin{array}{l}\text { The reservoir performs recreational } \\
\text { functions. }\end{array}$ & Yes & $\begin{array}{l}\text { Reservoir after technical } \\
\text { restoration for the purpose of } \\
\text { recreation }\end{array}$ & Yes & $\begin{array}{l}\text { The complex structure of ownership } \\
\text { renders it difficult, yet not impossible, to } \\
\text { initiate the restoration activities. }\end{array}$ & Yes & $\begin{array}{l}\text { No legal and formal obstacles to } \\
\text { implement restoration activities }\end{array}$ \\
\hline & 1.2 & Yes & $\begin{array}{c}\text { The contaminated bottom sediments } \\
\text { have been removed; no point or surface } \\
\text { pollutant sources. }\end{array}$ & Yes & $\begin{array}{l}\text { The contaminated bottom deposits } \\
\text { removed; the sewage management } \\
\text { in the catchment area settled }\end{array}$ & Yes & $\begin{array}{l}\text { No significant pollutant sources } \\
\text { identified }\end{array}$ & Yes & $\begin{array}{l}\text { No significant pollutant sources } \\
\text { identified }\end{array}$ \\
\hline & 1.3 & Yes & $\begin{array}{l}\text { Water transparency approximately } 0.5 \\
\text { m; no submerged vegetation }\end{array}$ & No & $\begin{array}{l}\text { After technical restoration, there } \\
\text { was a spontaneous revival of the } \\
\text { submerged vegetation. }\end{array}$ & Yes & $\begin{array}{c}\text { Water transparency }<1 \mathrm{~m} \text {; no submerged } \\
\text { vegetation }\end{array}$ & Yes & $\begin{array}{l}\text { Water transparency }<1 \mathrm{~m} ; \text { no } \\
\text { submerged vegetation }\end{array}$ \\
\hline & $\Sigma$ & YES & $\begin{array}{l}\text { No legal and formal obstacles; poor } \\
\text { reservoir's ecological condition }\end{array}$ & No & $\begin{array}{c}\text { No necessity to introduce the } \\
\text { submerged vegetation }\end{array}$ & YES & $\begin{array}{l}\text { The reservoir meets the criteria } \\
\text { qualifying it for ecological restoration }\end{array}$ & YES & $\begin{array}{c}\text { Poor reservoir's ecological condition } \\
\text { no legal and formal obstacles }\end{array}$ \\
\hline \multirow{4}{*}{ 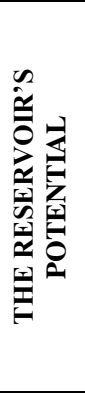 } & 2.1 & 1 & $\begin{array}{c}70 \% \text { of shore of steep slope partially } \\
\text { limits the ecological and social } \\
\text { potential of the reservoir }\end{array}$ & & & 2 & $\begin{array}{l}\text { More than } 50 \% \text { of the shore line } \\
\text { inhibited by reed vegetation }\end{array}$ & 1 & $\begin{array}{c}60 \% \text { of the shore of steep slope, } \\
\text { partially reducing the ecological and } \\
\text { social potential }\end{array}$ \\
\hline & 2.2 & 2 & $\begin{array}{l}\text { Location in a park area; very good } \\
\text { accessibility }\end{array}$ & & & 1 & $\begin{array}{l}\text { Reservoir located in close proximity to } \\
\text { residential development }\end{array}$ & 0 & $\begin{array}{l}\text { Reservoir located in close proximity to } \\
\text { residential development; access to the } \\
\text { reservoir limited }\end{array}$ \\
\hline & 2.3 & 0 & No projected impacts of mining & & & -2 & $\begin{array}{l}\text { Land subsidence - a threat to the } \\
\text { infrastructure enhancing the reservoir's } \\
\text { potential }\end{array}$ & -2 & $\begin{array}{l}\text { Significant land subsidence projected; } \\
\text { threat to the technical infrastructure }\end{array}$ \\
\hline & $\sum$ & 3 & $\begin{array}{l}\text { The reservoir's potential partially } \\
\text { limited by the unfavourable shore } \\
\text { zone character }\end{array}$ & & & 1 & $\begin{array}{l}\text { The strengthening of the high } \\
\text { reservoir's potential is limited by the } \\
\text { projected impact of mining }\end{array}$ & -1 & $\begin{array}{l}\text { The possibility of using the } \\
\text { reservoir's potential is limited by the } \\
\text { projected impact of mining }\end{array}$ \\
\hline \multirow{5}{*}{ 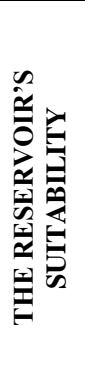 } & 3.1 & 0 & $\begin{array}{l}\text { Shallow depth (approx. } 2 \mathrm{~m} \text { ) and a } \\
\text { gentle bottom slope of the reservoir }\end{array}$ & & & 0 & $\begin{array}{l}\text { Shallow depth (approx. } 2.5 \mathrm{~m} \text { ) and a } \\
\text { gentle bottom slope of the reservoir }\end{array}$ & 0 & $\begin{array}{l}\text { Shallow depth (approx. } 2 \mathrm{~m} \text { ) and a } \\
\text { gentle bottom slope of the reservoir }\end{array}$ \\
\hline & 3.2 & 0 & The subsidence processes stabilized & & & -1 & $\begin{array}{c}\text { Further land subsidence by approx. } 1.5 \mathrm{~m} \\
\text { projected }\end{array}$ & -1 & $\begin{array}{c}\text { Land subsidence (approx. 1m) } \\
\text { projected }\end{array}$ \\
\hline & 3.3 & 0 & $\begin{array}{l}\text { A slight inflow of rainwater, constant } \\
\text { draining of the reservoir }\end{array}$ & & & -1 & $\begin{array}{l}\text { No natural outflow, water is pumped out } \\
\text { periodically }\end{array}$ & -2 & $\begin{array}{c}\text { Shores of steep slope; the reservoir } \\
\text { picks up significant amount of } \\
\text { rainwater }\end{array}$ \\
\hline & 3.4 & -1 & $\begin{array}{l}\text { No predatory fish; predominance of } \\
\text { zooplanktivorous fish }\end{array}$ & & & -1 & Grass carp stocking & 0 & Occurrence of predatory fish \\
\hline & $\sum$ & -1 & $\begin{array}{l}\text { ERUSV effectiveness limited by } \\
\text { ecological conditions }\end{array}$ & & & -3 & $\begin{array}{c}\text { A series of factors reduce the ERUSV } \\
\text { effectiveness }\end{array}$ & -3 & $\begin{array}{l}\text { ERUSV effectiveness significantly } \\
\text { limited by hydrological conditions }\end{array}$ \\
\hline
\end{tabular}


The above is a result of attractive location of the reservoir and the recreational character of the surrounding area (Fig. 3). The ecological potential of the reservoir is determined by the occurrence of reed vegetation in the reservoir's shore zone. Both the ecological and social values of the reservoir are limited by the poor water quality (Tab. 4).

The potential of the reservoir III to perform social values is limited mainly by a projected significant land subsidence resulting from mining operations. Nevertheless, due to the favourable character of the shore zone, the reservoir already performs ecological functions; still, it has the potential to broaden the scope of functions performed, once activities improving the water quality are conducted. The reservoir IV is characterized by the least favourable accessibility, and, as is the case of reservoir III, it will be subject to further land deformation processes due to the impact of mining activities (Tab. 4).

\section{Evaluation of the suitability of a reservoir for ecological restoration using submerged vegetation}

The most favourable conditions for the effective implementation of the ERUSV method have been found in the reservoir I. The only constraint is the excessive population of zooplanktivorous fish species that results from the lack of predatory fish in the reservoir.

All the analyzed reservoirs are characterized by a significant share of bottom favourable to the development of submerged vegetation. With regard to reservoir I and IV, the projected subsidence of the reservoir's bottom and, as a result, the reduction of the bottom area favourable for submerged vegetation, constitute an unfavourable factor. The steep slope of shores in the reservoir IV, along with a significant amount of water inflowing from the storm water system, lead to fluctuations in water level exceeding $2 \mathrm{~m}$. Reservoir III is also characterized by significant, yet smaller, fluctuations in the water level (Tab. 4).

\section{Discussion}

The aim of the proposed criteria is to develop a uniform system for evaluation of the potential of anthropogenic mine subsidence reservoirs, which constitute a significant part among the anthropogenic reservoirs (approx. 4770) that currently occur in the area of the Silesian Upland (Machowski and Rzętała, 2006). This is even of greater significance, as the forecasts show that new bodies of water of this type will be formed (Pelka-Gosciniak et al., 2008). The proposed evaluation has been developed as a tool for supporting the decision-making processes with regard to the use of the potential of mine subsidence reservoirs, and the possible courses of action that would enable a reasonable and optimal adaptation of such reservoirs. As has been shown by (Juszczak and Kędziora, 2003), the role of such bodies of water is significant, and is similar to the role of small reservoirs in the agricultural landscape.

The developed list of criteria refers to the current trends in the method of restoration of shallow reservoirs (Zalewski, 1999), and in the adaptation of public spaces that are to be appealing to the local people, and also should perform important ecological functions.

The restoration method supporting the growth of the submerged vegetation originates from the Theory of Alternative Stable States which assumes that inland reservoirs can exist under two alternative regimes: the transparent water regime (with the predominance of macrovegetation) or the turbid water regime (with the predominance 
of phytoplankton) (Scheffer, 1998; Wetzel, 2001; Moss, 2003). The literature indicates a series of successful examples of using the submerged vegetation in the process of restoration of shallow, eutrophic reservoirs (inter alia Pan, 2008; Dai, 2014; Li, 2014). The role of submerged vegetation is, inter alia, to: increase the stability of bottom sediments, improve the aerobic conditions, reduce the concentration of biogenic substances in the pelagic zone and their accumulation in the bottom sediments, as well as to provide shelter for zooplankton (whose main food is phytoplankton) and discharge allelopathic compounds that inhibit the growth of phytoplankton (Scheffer, 1998; Górniak and Dunalska, 2005; Walstad, 2013; Dai, 2014).

Due to complex biophysicochemical interactions, the state with the predominance of macrovegetation persists in a relatively wide range of fluctuations in the parameters of the habitat (the stability of the ecosystem); the shift to the state with the predominance of phytoplankton usually occurs exclusively due to a strong anthropogenic pressure, that may, for example, be connected with an intense inflow of biogenic substances to the reservoir, or to a significant disturbance of relationships within the trophic chain. The degradation processes reduce the water transparency, which is commonly the result of an increase in the phytoplankton biomass, and this leads to the recession of submerged vegetation, (Scheffer, 1989; Moss et al., 2003; Scheffer, 1998).

The water transparency parameter, used for the evaluation of reservoirs' water quality and measured with the use of Secchi disc, is one of the elements of the trophic state index of water (TSI). Nevertheless, it should be emphasized that due to the lowest level of accuracy, this parameter can be used in cases where other methods, e.g. the chlorophyll content, cannot be used (Carlson, 1977).

The processes of rapid decomposition of algae lead to a deterioration of the aerobic condition too, which in particular occurs in the summer. The process leads to qualitative and quantitative rearrangements within the water ecosystem, and as a result, to the elimination of hydrobiont taxons that are particularly susceptible to oxygen deficits. Thus, the functioning of the ecosystem is simplified and the biodiversity of the ecosystem is reduced. What is more, phytoplankton reservoirs are characterized by a low aesthetic value and they frequently constitute a sanitary threat, caused by toxic substances released by Cyanophyta. Since the state with the predominance of phytoplankton is the state of stable equilibrium, it usually tends to persist also after removing the factor that has caused the degradation (Scheffer, 1989; Sadecka and Waś, 2008).

The analyzed ERUSV method, subject to the fulfilment of specified shore conditions that have been taken into account in the developed evaluation, is characterized by a low cost ratio in relation to its effectiveness. In order to ensure the effectiveness of the expenditures incurred on restoration, the evaluation of the potential of reservoirs to perform the natural and social functions has been taken into consideration. The developed method of a three-stage evaluation renders it possible to make a comparison of the particular reservoirs with regard to their potential and, to choose those objects, whose ability to perform ecological and social functions may be significantly increased as a result of the implementation of the proposed restoration method.

The proposed method gives consideration to the most important factors that, based on current knowledge in this field, affect the effectiveness of the analyzed restoration method. Due to the complexity of water ecosystems and variety of particular anthropogenic water reservoirs, there may be some specific factors not accounted for in the criteria that will crucially affect the reservoir's potential and the effectiveness of the analyzed method. 
Thus, prior to the commencement of any restoration activities at a given object, it should be analyzed, whether the specific conditions of the given reservoir do not adversely affect the target type of use of the reservoir, and whether they do not reduce the effectiveness of the analyzed restoration method. Unfortunately, the comparison of the results with the literature is not possible as this type of evaluating anthropogenic objects has not been conducted so far, except for postindustrial areas, which has been proposed by (Trząski et al., 2008). These factors shall be subject to further study, which will lead to the standardization of the method.

The species composition and the manner of supporting the development of submerged vegetation should always be adjusted to the individual character of a given reservoir (this, inter alia, includes the trophic level, salinity, and availability of diasporas). Before conducting the restoration of a reservoir, a series of technical scale experiments should be performed in order to verify the effectiveness of the proposed method.

The evaluation of selected reservoirs that has been carried out with the use of this algorithm has proven the effectiveness of the proposed evaluation method. Nevertheless, only the practical implementation of the ecological restoration method supporting the growth of submerged vegetation in the reservoirs that have been determined with the use of this evaluation method will render it possible to fully assess the effectiveness and weaknesses of the proposed method.

Acknowledgement. The research was carried out within the framework of the statutory work of the Central Mining Institute in Katowice (Poland) entitled: Developing innovative method for reducing eutrophication of anthropogenic water reservoirs , No. 11310144-342.

\section{REFERENCES}

[1] Aravot, I. (1996): Integration of future users' evaluations into the process of urban revitalization. - Evaluation and Program Planning 19(1): 65-78.

[2] Avakyan, A.B., Boichenko, V.K., Saltankln, V.P. (1986): Evaluations of the recreational potential of reservoirs in design practice. - Hydrotechnical Construction 20(7): 421-425.

[3] Bender, E., Bigga, L., Maier, W. (2012): Urban Rivers - Vital Spaces Manual for Urban River Revitalisation. REURIS, p. 327.

[4] Boesch, D.F., Brinsfield, R.B., Magnien, R.E. (2001): Chesapeake Bay eutrophication: scientific understanding ecosystem restoration and challenges for agriculture. - J. Environ. Qual. 30: 303-320.

[5] Bolund, P., Hunhammar, S. (1999): Ecosystem services in urban areas. - Ecological Economics 29: 293-301.

[6] Bornette, G., Puijalon, S. (2011): Response of aquatic plants to abiotic factors: a review. - Aquatic Science 73: 1-14.

[7] Bradshaw, A.D. (1997): Restoration of mined lands - using natural processes. Ecological Engineering 8: 255-269.

[8] Cao, J. J., Wang, Y., Zhu, Z. L. (2012): Growth response of the submerged macrophyte Myriophyllum spicatum to sediment nutrient levels and water-level fluctuations. Aquatic Biology 17: 295-303.

[9] Carlson, R.E. (1977): A trophic state index for lakes. - Limnology and Oceanography 22(2): 361-369.

[10] Carpenter, S.R., Ludwig, D., Brock, W.A. (1999): Management of eutrophication for lakes subject to potentially irreversible change. - Ecological Applications 9: 751-771. 
[11] Carpenter, R.S., Lathrop, R.C. (1999): Lake restoration: capatibiles and needs. Hydrobiologia 395/396: 19-28.

[12] Ciecierska, H. (2008): Macrophyte based indices of the ecological state of lakes [Makrofity jako wskaźniki stanu ekologicznego jezior]. Dissertations and Monographs 139, University of Warmia and Mazury in Olsztyn.

[13] Ciecierska, H., Kolada, A. (2014): ESMI: a macrophyte index for assessing the ecological status of lakes. - Environ Monit Assess. 186(9): 5501-5517.

[14] Cook, G.D., Lombardo, P., Brant C. (2001): Shallow and Deep Lakes: Determining Successful Management Options. - Lakeline, 42-45.

[15] Coops, H., Beklioglu, M., Crisman, T.L. (2003): The role of water level fluctuations in shallow lake ecosystems-workshop conclusions. - Hydrobiologia 506-509: 23-27.

[16] Corrigan, J.R., Egan, K.J., Downing, J.A. (2009): Aesthetic Values of Lakes and Rivers In: Likens, G. E. (ed.) Encyclopaedia of Inland Waters, New York pp 2-12.

[17] Dai, Y., Tang, H., Chang, J., Wu, Z., Liang, W. (2014): What's better, Ceratophyllum demersum L. or Myriophyllum verticillatum L., individual or combined? - Ecological Engineering 70: 397-401

[18] de Groot R.S., Alkemade R., Braat L., Hein L., Willemen L. (2010): Challenges in integrating the concept of ecosystem services and values in landscape planning, management and decision making. - Ecological Complexity 7: 260-272.

[19] Duarte, C.M., Kalff, J. (1986): Littoral slope as a predictor of the maximum biomass of submerged macrophyte communities. - Limnology \& Oceanography 31: 1072-1080

[20] Eppesen, E., Lauridsen, T., Mitchell, S.F., Burns, C.W. (1997): Do planktivorous fish structure the zooplankton communities in New Zealand lakes? - New Zealand Journal of Marine and Freshwater Research 31: 163-173.

[21] Gächter R., Imboden D. (1985): Lake restoration. - In: Stumm, W. (ed.) Chemical Processes in Lakes. John Wiley \& Sons, pp. 365-388.

[22] Gorman, M.W., Zimmer, K.D., Herwig, B.R., Hanson, M.A., Wright R. G., Vaughn, S.R., Younk J.A. (2014): Relative importance of phosphorus, fish biomass, and watershed land use as drivers of phytoplankton abundance in shallow lakes. - Science of The Total Environment 466-467:849-855

[23] Górniak, D., Dunalska, J. (2005): Changeability of structures and activities of bacteriobenthos of shallow lakes of Mazurian Landscape Park (North-East Poland). Acta Univer. Nicalai Copernici Limnology 25(113): 45-54.

[24] Hassall, C. (2014): The ecology and biodiversity of urban ponds. - WIREs Water. 2: 187206.

[25] Hilt, S., Grossb, E.M, Hupfer, M, Morscheid, H, Mahlmann, J., Melzer, A., Poltz, J., Sandrock, S., Scharf, E.M., Schneider, S, Van De Weyer, K. (2006): Restoration of submerged vegetation in shallow eutrophic lakes - A guideline and state of the art in Germany. Limnologica - Ecology and Management of Inland Waters 36(3): 155-171.

[26] Juszczak, R., Kędziora, A. (2003): Threats and deterioration of small water reservoir located within Wyskoć catchment. - Polish Journal of Environmental Studies 12(5): 567573.

[27] Jankowski A.T., Molenda T., Rzętała M. (2001): Reservoirs in subsidence basins and depression hollows in the Silesian Upland - selected hydrological matters. - Limnological Review 1: 143-150.

[28] Jankowski A.T., Rzętała M. (2004): State of limnological research in the Upper Silesian Region [Stan badań limnologicznych w regionie górnośląskim]. - In: A.T. Jankowski, M. Rzętała (ed.) Lakes and artificial water reservoirs: functioning, revitalization and protection [Jeziora i sztuczne zbiorniki wodne - funkcjonowanie, rewitalizacja i ochrona]. Sosnowiec, Uniwersytet Śląski - Wydział Nauk o Ziemi, Polskie Towarzystwo Limnologiczne, Polskie Towarzystwo Geograficzne - Oddział Katowicki, s.101-115. 
[29] Jeppesen, E., Søndergaard, M., Meerhoff, M., Lauridsen, T.L., Jensen, J.P. (2007): Shallow lake restoration by nutrient loading reduction: some recent findings and challenges ahead. - Hydrobiologia 584: 239-252.

[30] Kosten, S., Kamarainen, A., Jeppesen, E., Van Nes, E.H., Peeters, E.T.H.M., Mazzeo, N., Sass, L., Hauxwell, J., Hansel-Welch, N., Lauridsen, T.L., Søndergaard, M., Bachmann, R.W., Lacerot, G., Scheffer, M. (2009): Climate-related differences in the dominance of submerged macrophytes in shallow lakes. - Global Change Biol. 15: 2503-2517.

[31] Krolová, M., Č́žzová, H.; Hejzlar, J. (2010): Factors affecting the occurrence of aquatic macrophytes in the Lipno reservoir. - Silva Gabreta 16(2): 61-92.

[32] Li, K., He, W., Hu, Q., Gao, S. (2014): Ecological restoration of reclaimed wastewater lakes using submerged plants and zooplankton. - Water and Environment Journal 28: 323-328.

[33] Machowski, R., Rzętała, M. (2006): The Silesia Upland and its egde as "anthropogenic lakeland". - Wszechświat 107(1-3): 45-50.

[34] Mandic, D., Jovanovic, P., Bugarinovic, M. (2014): Two-phase model for multi-criteria project ranking: Serbian Railways case study. - Transport Policy: 36: 88-104.

[35] Marschalko, M.,Treslin, L., Fuka, M. (2009): Possible impact of current and former mining activities on a research locality in the Ostrava - Karvina District. - Górnictwo i Geoinżynieria 33(1): 429-442.

[36] Mazurder, A., Taylor, W.D., Mcqueen, D.J., Lean, D.R.S. (1990): Effects of Fish and Plankton on Lake Temperature and Mixing Depth. - Science 247(4940): 312-315.

[37] Meijer, M.L., De Boois, I., Scheffer, M., Portielje, R., Hosper, H., (1999): Biomanipulation in shallow lakes in The Netherlands: an evaluation of 18 case studies. Hydrobiologia 408/409: 13-30.

[38] Millar S. Rhode (2010) Island LID Site Planning and Design Guidance for Communities. Riparian buffer standards. Rhode Island Department of Environmental Management, Rhode Island

[39] Mitsch, W. J., Gosselink, J. G. (2007):Wetlands. Hoboken.

[40] Moreno, M.J. (2011): Analysis of the relationship between submerged aquatic vegetation (SAV) and water trophic status of lakes clustered in Northwestern Hillsborough County, Florida. - Water Air Soil Pollut. 214: 539-546.

[41] Moss, B. (1998): Shallow Lakes Biomanipulation and Eutrophication. - Scope Newsletter 29: 2-45.

[42] Moss, B., Stephen, D., Alvare, C., Becares, E., Van De Bund, W., Van Donk, E., De Eyto, E., Feldmann, T., Fernández-Aláez, C., Fernández-Aláez, M. (2003): The determination of ecological status in shallow lakes - a tested system (ECOFRAME) for implementation of the European Water Framework Directive. - Aquatic Conservation: Marine and Freshwater Ecosystems 13: 507-549.

[43] Mušič, B, Cotič, B. (2006): Brownfield regeneration management. From education to practice.http://www.cobraman-ce.eu/Portals/0/CM\%20newsletter/Cobraman\%2006_New sletter_\%20FINAL\%20brochure.pdf

[44] Naselli-Flores, L. (2008): Urban Lakes: Ecosystems at Risk, Worthy of the Best Care. In Proceedings of Taal 2007: The 12th World Lake Conference. IND, 1333-1337.

[45] Padial, A.A.; Thomaz S.M. (2008): Prediction of the light attenuation coefficient through the Secchi disk depth: Empirical modeling in two large Neotropical ecosystems. Limnology 9: 143-151.

[46] Pan, G., Chen, H., Zou, H., Tian, B., Yuan, X., Chen, J., Zhang, M., Yang, B. (2008): Turning Back Catastrophic Shifts in Shallow Lakes: Large Scale Harmful-Algae-Bloom (HAB) Removal and Submerged Vegetation Restoration Using Modified-Local-Soil Technology - In: Sengupta, M. and Dalwani, R. (ed.) Proceedings of Tall: The 12th World Lake Conference.

[47] Pelka-Gosciniak, J., Rahmonov, O., Szczypek, T. (2008): Water reservoirs in subsidence depressions in landscape of the Silesian upland (southern Poland The 7th International 
Conference Faculty of Environmental Engineering Vilnius Gediminas Technical University pp. 22-23.

[48] Peres, R., da Silva, R. (2013): Interfaces of urban environmental management and regional management: analysis of the relationship between Municipal Master Plans and Watershed Plans. - Brazilian Journal of Urban Management, 5(2), s. 13-25.

[49] Petríková, D., Vojvodíková, B. (2012): Brownfields - Handbook BROWNTRANS. VŠB - Technical University of Ostrava, ISBN 978-80-248-2893-0.

[50] Pierzchała, Ł. (2011): Study of correlation between hydrochemical water parameters and vegetation characteristics in flooded mine subsidences [Studium závislostí mezi hydrochemickými parametry a charakterem vegetace zvodnělých poklesových kotlin]. $\mathrm{PhD}$ Thesis, VŠB-TUO, HGF, Institute of Environmental Engineering. 79 s. (unpl.)

[51] Pierzchała, Ł., Sierka, E. (2009): Influence of reclamation type of subsidence reservoirs on vegetation differentiation in surrounding area. In 13th International Conference Environment and Mineral Processing \& Exhibition, VŠB - Technical University of Ostrava, Czech Republic 3: 239-245.

[52] Portielje, R., Van Der Molen, D.T. (1999): Relationships between eutrophication variables: from nutrient loading to transparency. - Hydrobiologia 408/409, 375-387.

[53] Prus, T., Prus, M., Prus, P., Ozimek T. (2006): The ecological characteristics of Solina and Myczkowce storage reservoirs [Charakterystyka ekologiczna zbiorników zaporowych Solina i Myczkowce na Sanie]. II Scientific-Technical Conference "Blue San" 33: 21-28.

[54] Qin, R.S. (2006): Mesoscopic interparticle potentials in the lattice Boltzmann equation for multiphase fluids. - Physical Review 73: 1539-3755.

[55] Rooney, R. C. and Bayley, S. E. (2010): Quantifying a stress gradient: An objective approach to variable selection, standardization and weighting in ecosystem assessment. Ecological Indicators 10: 1174-1183.

[56] Sadecka, Z., Waś, J. (2008): Non-invasive methods for the improvement of the quality of water reservoirs [Nie inwazyjne metody poprawy jakości zbiorników wodnych perspektywa] - In: Sadecka Z., Myszograj S. (ed.) Wastewater and sewage sludge treatment, Zielona Góra, pp. 3.

[57] Scheffer, M. (1989): Alternative stable states in eutrophic, shallow freshwater systems: a minimal model. - Hydrological Bulletin 23: 73-83.

[58] Scheffer, M. (1998): Ecology of Shallow Lakes. London, pp 3- 31.

[59] Scheffer, M. (2004): Ecology of shallow lakes. Population and Community Biology Series 22. Springer Verlag. 357p.

[60] Scheffer, M., Carpenter, S.R. (2003): Catastrophic regime shifts in ecosystems: linking theory to observation. - Trends in Ecology \& Evolution 18: 648-656.

[61] Scheffer, M., Szabo, S., Gragnani, A., Van-Nes, E. H., Rinaldi, S., Kautsky, N., Norberg, J., Roijackers, R. M. M., Franken, R. J. M. (2003): Floating plant dominance as a stable state. Proceedings of the National Academy of Science of the United States of America 100: 4040-4045.

[62] Schindler, D. W. (2006): Recent advances in the understanding and management of eutrophication. - Limnol. Oceanogr. 51(1)2: 356-363.

[63] Sierka, E., Molenda, T., Chmura, D. (2009): Environmental repercussion of subsidence reservoirs reclamation. - Journal of Water and Land Development, 13a: 41-52.

[64] Sierka, E., Stalmachová, B., Molenda, T., Chmura, D., Pierzchała, Ł. (2012): Environmental and socio-economic importance of mining subsidence reservoirs, BEN Technicka Literatura Praha, pp. 1-112.

[65] Słowik M. (2015): Is history of rivers important in restoration projects? The example of human impact on a lowland river valley (the Obra River, Poland). Emerging geomorphic approaches to guide river management practices. - Geomorphology 251: 50-63.

[66] Søndergaard, M., Jeppesen, E. Jensen J. P. (2005): Pond or lake: does it make any difference? - Archiv Fur Hydrobiologie 162: 143-165. 
[67] Stoddard, J. L., Larsen, D. P., Hawkins, C. P., Johnson, R. K., Norris R. H. (2006): Setting expectations for the ecological condition of streams: the concept of reference condition. - Ecological Applications 16: 1267-1276.

[68] Świerk, D., Szpakowska, B. (2009): Estimation of recreational values of chosen water reservoirs and littoral zone functioning [Ocena wartości rekreacyjnej wybranych zbiorników miejskich a funkcjonowanie strefy litoralnej]. - Science Nature Technologies 3(1): 1-11.

[69] Trząski, L., Mana, V. (2008): Monetary value assessment of biotopes in the Bobrek River Valley, Sosnowiec - a methodology proposal for Poland. Prace Naukowe GIG. Górnictwo i Środowisko. Główny Instytut Górnictwa, 3: 70-90.

[70] Trząski, L. Olszewski, P. Bondaruk, J. Gorgoń, J. Jaros, B. Krupanek, J. StarzewskaSikorska, A. (2008): Method of drawing up inventory and classification of post-industrial terrains, including mining. Study of algorithm of assessment and classification of postindustrial terrains. - Journal of Sustainable Mining 1: 53-79.

[71] Walstad, D.L. (2013): Ecology of the Planted Aquarium. A Practical Manual and Scientific Treatise Echinodorus Publishing, 3th edition, pp. 1-194.

[72] Weisner, S.E.B., Strand, J.A., Sandesten, H. (1997): Mechanisms regulating abundance of submerged vegetation in shallow eutrophic lakes. - Oecologia 109: 592-599.

[73] Wetzel, R.G. (2001): Limnology: Lake and River Ecosystems. 3'd Edition. Academic Press, San Diego, CA, USA. pp. 1006.

[74] Zalewski, M. (1999): Minimising the risk and amplifying the opportunities for restoration of shallow reservoirs. - Hydrobiologia. 395/396: 107-114.

\begin{abstract}
W pracy przedstawiono propozycję kryteriów oceny zbiorników, powstałych $\mathrm{w}$ nieckach osiadania na terenach podziemnej eksploatacji surowców mineralnych, do rekultywacji i zagospodarowania, aby mogły pełnić funkcje przyrodnicze i społeczne w przestrzeni miejskiej. Analizie poddano kryteria oceny potencjału zbiorników $(P)$ i wskazano czynniki istotne dla przydatności $(U)$ przedmiotowych obiektów do zastosowania rekultywacji biologicznej z wykorzystaniem roślinności zanurzonej. Możliwość wykorzystania zaproponowanych kryteriów (jakościowych - tak/nie ilościowych ocenionych w skali: $-2,-1,0,1,2)$, zweryfikowano na przykładzie losowo wybranych 4 zbiornikach, powstałych w nieckach osiadania na Górnym Śląsku._Uzyskane rezultaty wykazały, że zbiorniki różnią się ocenionym potencjałem (P: od -1 do 3) i przydatnością (U: od -3 do -1).

Stwierdzono, że zaproponowane 3 etapy oceny potencjału i przydatności zbiorników do zagospodarowania, pozwalają na kategoryzację i typowanie akwenów do zabiegów rekultywacyjnych. Jest to tym istotniejsze, że zbiorniki w nieckach osiadania stanowią większość wśród zbiorników antropogenicznych funkcjonujących aktualnie na obszarach pogórniczych.
\end{abstract}

